\title{
Implementation of Technology Such As Enterprises Resource Planning (ERP) Through Integration of Human Capital with Quality using Analytic Hierarchical Process (AHP)
}

\author{
P.V.S. Kiran, A. Mohammed Faisal
}

\begin{abstract}
Information technology Such as Enterprises Resource Planning (ERP) supports the processes of electronic human resource management (e-HRM) but it lacks the other factors such human capital and quality in decision making. Human capital is related to the skill and knowledge of employee. Total Quality Management (TQM) is more emphasis on the internal customer that includes the employee within the organization. Human Capital (HC) and Quality can be integrated to improve the quality of the output. Many studies have integrated the Quality with HRM through e-HRM to improve the performances but only a few studies have done for e-HRM with the integration of $\mathrm{HC}$ with Quality. The purpose of this study is to implement the e-HRM through the integration of HC with Quality using Analytic Hierarchy Process (AHP). The exploration type of research design to integrate the $\mathrm{HC}$ with Quality is analyzed using AHP analysis based on the critical success factors (CSFs). The analysis of AHP is resulted that Employee involvement $(E I=$ 0.234), Training, Education \& Learning $(T L=0.234)$, Quality Measures $(Q M=0.146)$, Performance Appraisal $(P A=0.131)$ and Quality Factors $(Q F=0.096)$ are selected for implementation of the e-HRM through the integration of HC with Quality. Based on the five CSFs, the conceptual model can be designed for implementation of the e-HRM through the integration of $\mathrm{HC}$ with Quality. The conceptual model for implementation of the e-HRM through the integration of $\mathrm{HC}$ with Quality needs to be empirically tested.
\end{abstract}

Keywords : AHP, CSFs, ERP, Human Capital, Quality.

\section{INTRODUCTION}

T Technology Such as Enterprises Resource Planning (ERP) has been a great impact on the reduction of the time taken for processes of electronic human resource management (e-HRM) [1]. Information technology supports the processes of electronic human resource management (e-HRM) at the different level, but it lacks the other factors

Revised Manuscript Received on December 30, 2019.

* Correspondence Author

P.V.S. Kiran, School of Management Studies, Vels Institute of Science, Technology \& Advanced Studies, Chennai, India. Email: solomonkiran@gmail.com

A. Mohammed Faisal*, Correspondence Author, School of Management Studies, Vels Institute of Science, Technology \& Advanced Studies, Chennai, India. Email: a.mohd.faisal@gmail.com

(C) The Authors. Published by Blue Eyes Intelligence Engineering and Sciences Publication (BEIESP). This is an open access article under the CC BY-NC-ND license (http://creativecommons.org/licenses/by-nc-nd/4.0/)

such human capital and quality in decision making [2]. Total Quality Management (TQM) is more emphasis on the internal customer when compared to external customers. Internal customer includes the employee within the organization. Human capital is related to the skill and knowledge of employee. To improve the quality of the output, the organizations need to have a human capital with the integration of TQM.

The concept of human capital through human resource management (HRM) was integrated with TQM in operations and quality [3]. Then, the later studies are more emphasized on implementation of Human Capital through HRM. The model was developed by the researchers based on the human resource architecture and human capital theory [2]. The usage of human capital was examined through strategic HRM on the performance of the firm [5] and human resource (HR) configuration supported for four employment modes [6]. Some researchers found that the human capital had significantly impacted on the learning and performance [7] and HR structure were important for the development of human capital [8]. Later, human capital was studied for customer interactions in the service organizations [9]. The critical success factors (CSFs) such as organizational performance [10], Employment relationship [11] and leadership with learning [12] were studied with the human capital.

Many studies have integrated the Quality with HRM to improve the performances [13] through e-HRM [1] but only a few studies have done with the integration of Human Capital (HC) with Quality (Tab. 1 and 2). The weights of each CSF using Analytic Hierarchy Process (AHP) [14] can support for integration of HC with Quality. The basic TQM concepts to improve the quality measure $[6,15]$ can be integrated with HC. The purpose of this study is to implement the e-HRM through the integration of HC with Quality using Analytic Hierarchy Process (AHP).

Tab. 1 Literature Survey of CSFs based on the Quality and $\mathrm{HC}$

\begin{tabular}{|c|c|c|c|c|c|c|c|c|c|c|}
\hline \multirow{2}{*}{ CSFs } & \multicolumn{10}{|c|}{ Authors } \\
\cline { 2 - 11 } & $\mathbf{1}$ & $\mathbf{2}$ & $\mathbf{3}$ & $\mathbf{4}$ & $\mathbf{5}$ & $\mathbf{6}$ & $\mathbf{7}$ & $\mathbf{8}$ & $\mathbf{9}$ & $\mathbf{1 0}$ \\
\hline Leadership & & & & & & & & & & $*$ \\
\hline $\begin{array}{c}\text { Quality } \\
\text { Factors }\end{array}$ & $*$ & & & & $*$ & & $*$ & & & \\
\hline
\end{tabular}


Implementation of Technology Such As Enterprises Resource Planning (ERP) Through Integration of Human Capital with Quality using Analytic Hierarchical Process (AHP)

\begin{tabular}{|c|c|c|c|c|c|c|c|c|c|c|}
\hline \multirow{2}{*}{ CSFs } & \multicolumn{7}{|c|}{ Authors } \\
\cline { 2 - 10 } & $\mathbf{1}$ & $\mathbf{2}$ & $\mathbf{3}$ & $\mathbf{4}$ & $\mathbf{5}$ & $\mathbf{6}$ & $\mathbf{7}$ & $\mathbf{8}$ & $\mathbf{9}$ & $\mathbf{1 0}$ \\
\hline Teamwork & & & $*$ & & & $*$ & & & & \\
\hline $\begin{array}{c}\text { Continuous } \\
\text { Improvement }\end{array}$ & $*$ & & & & & & & & & \\
\hline $\begin{array}{c}\text { Employee } \\
\text { Involvement }\end{array}$ & $*$ & $*$ & $*$ & $*$ & & $*$ & & & $*$ & \\
\hline $\begin{array}{c}\text { Training, } \\
\text { Education \& } \\
\text { Learning }\end{array}$ & $*$ & & & $*$ & $*$ & $*$ & & $*$ & & $*$ \\
\hline $\begin{array}{c}\text { Communicatio } \\
\text { n }\end{array}$ & & & $*$ & & & & & & & \\
\hline $\begin{array}{c}\text { Rewards and } \\
\text { Recognition }\end{array}$ & $*$ & & & $*$ & & & & & & \\
\hline $\begin{array}{c}\text { Performance } \\
\text { Appraisal }\end{array}$ & $*$ & & & $*$ & & & $*$ & $*$ & $*$ & \\
\hline Staffing & $*$ & & & & & $*$ & & & & \\
\hline $\begin{array}{c}\text { Quality } \\
\text { Measures } \\
\text { Capital } \\
\text { Intensity }\end{array}$ & & & $*$ & $*$ & $*$ & $*$ & $*$ & $*$ & & \\
\hline $\begin{array}{c}\text { Productivity } \\
\text { Tab. 2 Total }\end{array}$ & & & $*$ & $*$ & & & & & & \\
\hline
\end{tabular}

Tab. 2 Total no. of CSFs based on the literature survey of Quality and HC

\begin{tabular}{|c|c|}
\hline CSFs & Total \\
\hline Employee Involvement & 6 \\
\hline Training, Education \& Learning & 6 \\
\hline Performance Appraisal & 5 \\
\hline Quality Measures & 5 \\
\hline Quality Factors & 3 \\
\hline Productivity & 2 \\
\hline Teamwork & 2 \\
\hline Rewards and Recognition & 2 \\
\hline Staffing & 1 \\
\hline Leadership & 1 \\
\hline Continuous Improvement & 1 \\
\hline Communication & \\
\hline Capital Intensity &
\end{tabular}

\section{RESEARCH METHODOLOGY FOR ANALYTIC HIERARCHY PROCESS (AHP)}

The type of research design is the exploration to implement the e-HRM through the integration of HC with Quality. In order to integrate the HC with Quality, AHP analysis is used for exploration based on the CSFs. Business Performance Management Singapore (BPMSG) is run by Klaus D. Goepel who developed a software that is called as AHP Online System (AHP-OS) to analysis the AHP through web [16]. AHP is analyzed through the following steps:

- Select the CSFs based on the highest number of articles that was considered by the researchers (Tab. 3)

- Build an AHP model based on the selection of the CSFs (Fig. 1)

- Assessment of an AHP model using AHP-OS

o Input the CSFs that were selected based on the consideration of the researchers

o Perform pairwise comparison based on AHP scale (1-9) for the selected CSFs (Fig. 2)

o Determine the decision matrix for the selected CSFs (Tab. 4)

o Determine the normalized weights for each CSF

Tab. 3 Selection of CSFs for AHP analysis based on the highest number of articles

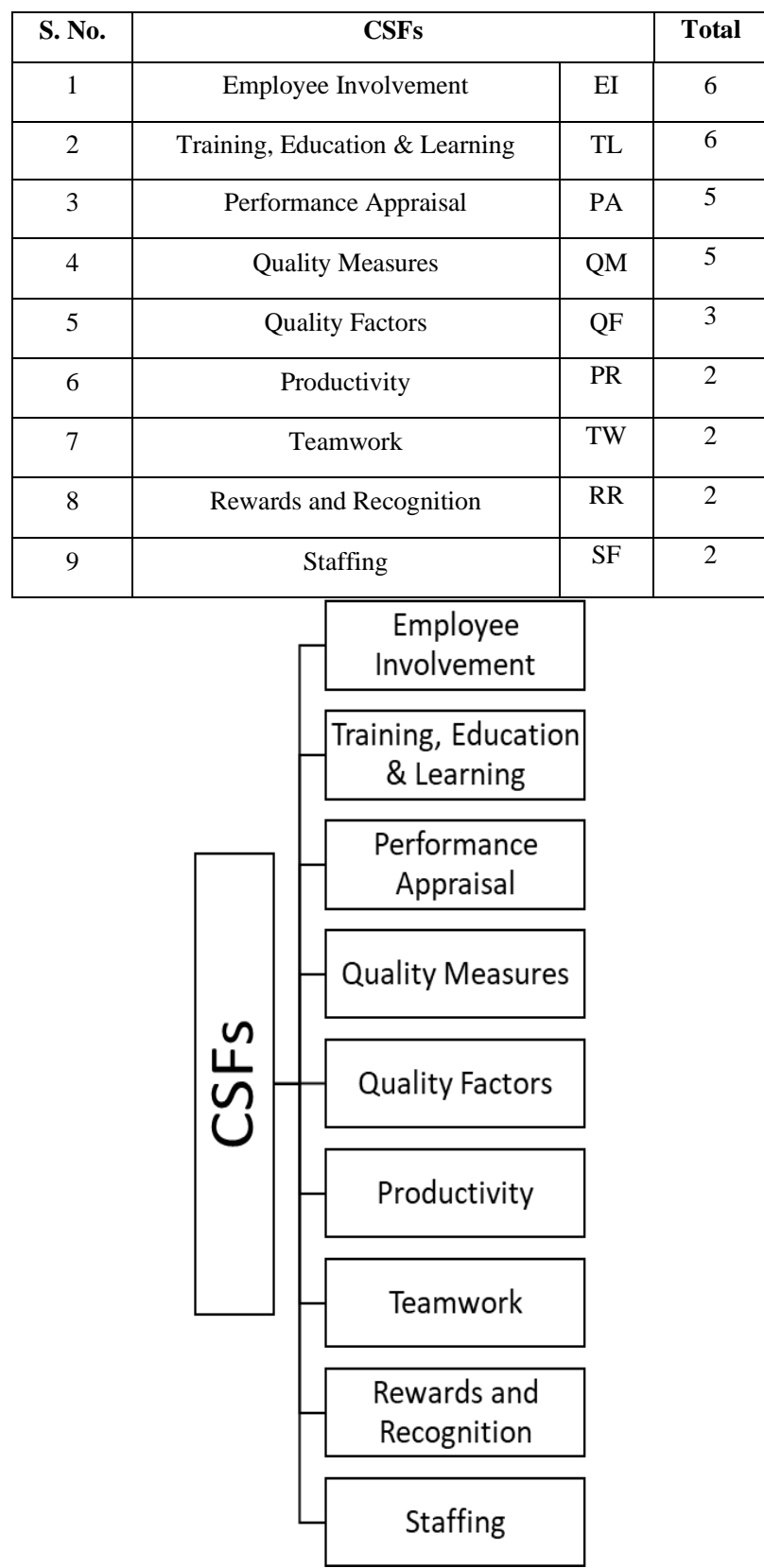

Fig. 1 An AHP model for integration of HC with Quality based on the selection of the CSFs

Published By:

Blue Eyes Intelligence Engineering \& Sciences Publication 


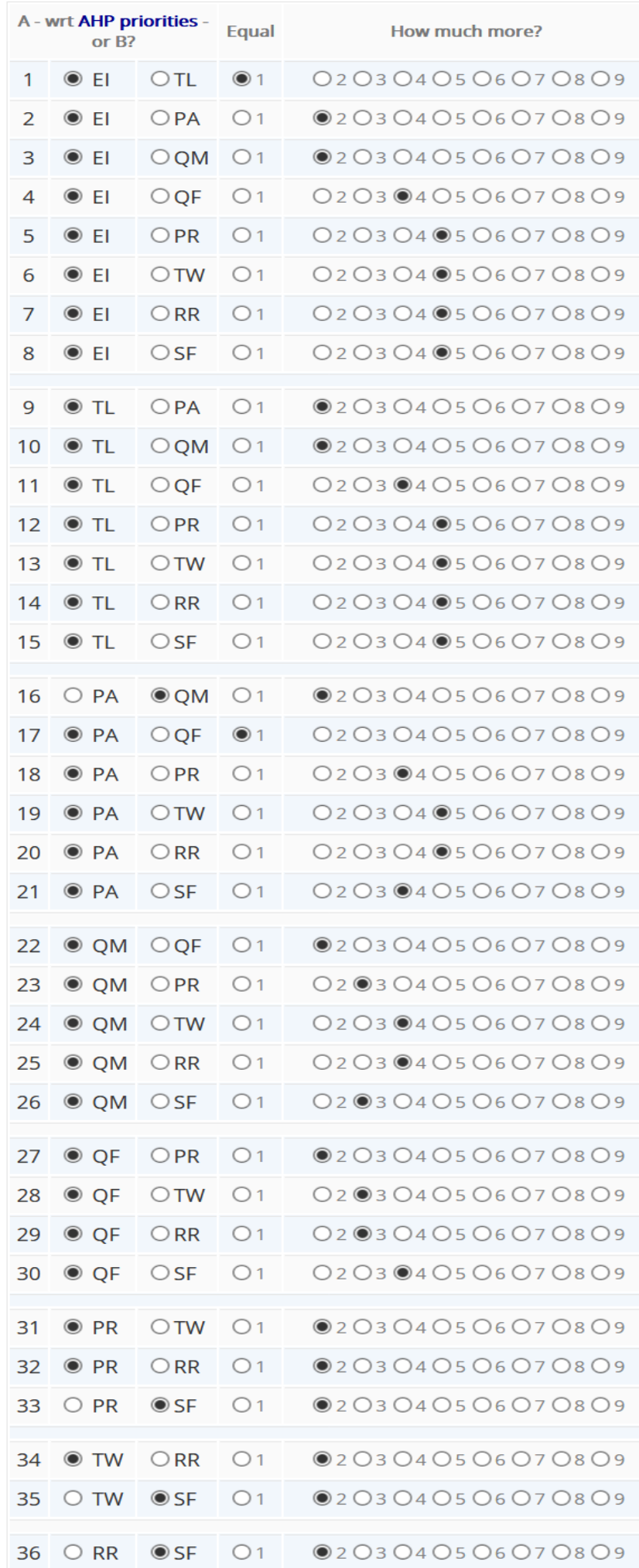

Fig. 2 Pairwise comparison for the selected CSFs through Web Analysis [16]
Tab. 4 The decision matrix for the selected CSFs

\begin{tabular}{|c|c|c|c|c|c|c|c|c|c|}
\hline & $\mathrm{EI}$ & $\mathrm{TL}$ & $\mathrm{PA}$ & $\mathrm{QM}$ & $\mathrm{QF}$ & $\mathrm{PR}$ & $\mathrm{TW}$ & $\mathrm{RR}$ & $\mathrm{SF}$ \\
\hline $\mathrm{EI}$ & 1 & 1.00 & 2.00 & 2.00 & 4.00 & 5.00 & 5.00 & 5.00 & 5.00 \\
\hline $\mathrm{TL}$ & 1.00 & 1 & 2.00 & 2.00 & 4.00 & 5.00 & 5.00 & 5.00 & 5.00 \\
\hline $\mathrm{PA}$ & 0.50 & 0.50 & 1 & 0.50 & 1.00 & 4.00 & 5.00 & 5.00 & 4.00 \\
\hline $\mathrm{QM}$ & 0.50 & 0.50 & 2.00 & 1 & 2.00 & 3.00 & 4.00 & 4.00 & 3.00 \\
\hline $\mathrm{QF}$ & 0.25 & 0.25 & 1.00 & 0.50 & 1 & 2.00 & 3.00 & 3.00 & 4.00 \\
\hline $\mathrm{PR}$ & 0.20 & 0.20 & 0.25 & 0.33 & 0.50 & 1 & 2.00 & 2.00 & 0.50 \\
\hline $\mathrm{TW}$ & 0.20 & 0.20 & 0.20 & 0.25 & 0.33 & 0.50 & 1 & 2.00 & 0.50 \\
\hline $\mathrm{RR}$ & 0.20 & 0.20 & 0.20 & 0.25 & 0.33 & 0.50 & 0.50 & 1 & 0.50 \\
\hline $\mathrm{SF}$ & 0.20 & 0.20 & 0.25 & 0.33 & 0.25 & 2.00 & 2.00 & 2.00 & 1 \\
\hline
\end{tabular}

\section{RESULT ANALYSIS}

AHP analysis has completed nearly 36 pairwise comparison for the entire CSFs. After the five iterations, the Principle Eigen Value (PEV =9.425) and Consistency Ration $(C R=0.037)$ showed the inconsistency is less for priorities of decision matrix. The AHP analysis (Tab. 5 and Fig. 3) showed the normalized weight of each CSFs for implementation of the e-HRM through the integration of HC with Quality. The normalized weights of Employee involvement $(\mathrm{EI}=0.234)$, Training, Education \& Learning $(\mathrm{TL}=0.234)$ are the essential CSFs for implementation of the e-HRM through the integration of the HC and TQM. The normalized weights of Quality Measures $(\mathrm{QM}=0.146)$, Performance Appraisal (PA = 0.131) and Quality Factors (QF $=0.096$ ) are moderately important, but the normalized weight of other Factors $(\mathrm{SF}=0.0 .05$; $\mathrm{PR}=0.045$; $\mathrm{TW}=0.035$; $\mathrm{RR}=$ 0.03 ) is the least important for implementation of the e-HRM through the integration of HC with Quality.

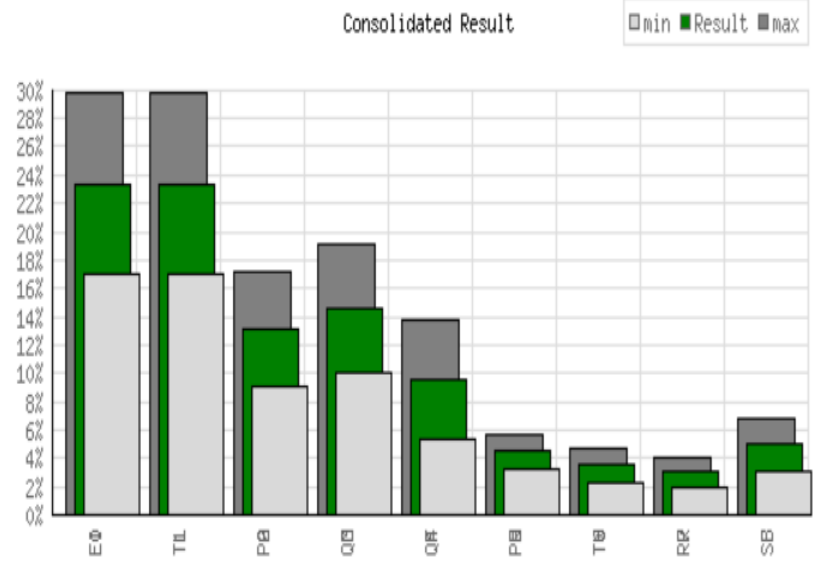

Fig. 3 Consolidated Result of each factor for implementation of the e-HRM through the integration of HC with Quality 
Implementation of Technology Such As Enterprises Resource Planning (ERP) Through Integration of Human Capital with Quality using Analytic Hierarchical Process (AHP)

Tab. 5 Normalized Weight and Raking of each CSF for implementation of the e-HRM through the integration of HC with Quality

\begin{tabular}{|c|c|c|c|c|}
\hline S. No. & \multicolumn{2}{|c|}{ CSFs } & $\begin{array}{c}\text { Normalized } \\
\text { Weight }\end{array}$ & Rank \\
\hline 1 & $\begin{array}{c}\text { Employee } \\
\text { Involvement }\end{array}$ & EI & 0.234 & 1 \\
\hline 2 & $\begin{array}{c}\text { Training, Education } \\
\text { \& Learning }\end{array}$ & TL & 0.234 & 1 \\
\hline 3 & Quality Measures & QM & 0.146 & 3 \\
\hline 4 & $\begin{array}{c}\text { Performance } \\
\text { Appraisal }\end{array}$ & PA & 0.131 & 4 \\
\hline 5 & Quality Factors & QF & 0.096 & 5 \\
\hline 6 & Staffing & SF & 0.05 & 6 \\
\hline 7 & Productivity & PR & 0.045 & 7 \\
\hline 8 & Teamwork & TW & 0.035 & 8 \\
\hline 9 & Rewards and & RR & 0.03 & 9 \\
\hline
\end{tabular}

\section{CONCLUSION}

The analysis of AHP is resulted that Employee involvement $(\mathrm{EI}=0.234)$, Training, Education \& Learning $(\mathrm{TL}=0.234)$, Quality Measures $(\mathrm{QM}=0.146)$, Performance Appraisal $(\mathrm{PA}=0.131)$ and Quality Factors $(\mathrm{QF}=0.096)$ are the essential CSFs for implementation of the e-HRM through the integration of the $\mathrm{HC}$ and Quality, but the normalized weight of other Factors ( $\mathrm{SF}=0.0 .05$; $\mathrm{PR}=0.045$; TW $=0.035 ; \mathrm{RR}=0.03$ ) is the least important for implementation of the e-HRM through the integration of HC with Quality. So the five CSFs such as Employee involvement $(\mathrm{EI}=0.234)$, Training, Education \& Learning ( $\mathrm{TL}=0.234)$, Quality Measures $(\mathrm{QM}=0.146)$, Performance Appraisal $(\mathrm{PA}=$ 0.131) and Quality Factors $(\mathrm{QF}=0.096)$ are selected for implementation of the e-HRM through the integration of HC with Quality. Based on the five CSFs, the conceptual model can be designed for implementation of the e-HRM through the integration of HC with Quality. The conceptual model for implementation of the e-HRM through the integration of $\mathrm{HC}$ with Quality needs to be empirically tested.

\section{REFERENCES}

1. Stone, D.L. and Dulebohn, J. H. (2013). Emerging issues in theory and research on electronic human resource management (e-HRM), Human Resource Management Review, Vol. 23, No. 1, pp. 1-5

2. Schalk, R., Timmerman, V. and Heuvel, S. (2012). How strategic considerations influence decision making on e-HRM applications, Human Resource Management Review, Vol. 23, No. 1, pp. 84-92.

3. Snell, S. C. and Dean, J. W. (1992). Integrated Manufacturing and Human Resource Management: A Human Capital Perspective, Academy of Management Journal, Vol. 35, No. 3, pp. 467-504.

4. Lepak, D. P. and Snell, S. A. (1999). Human Resource Architecture: Towards a theory of Human Capital allocation and development, Academy of Management Journal, Vol. 24, No. 1, pp. 31-48.

5. Richard, O. C. and Johnson, N. B. (2001). Strategic human resource management effectiveness and firm performance, International Journal of Human Resource Management, Vol. 12, No. 2, pp. 299-310.

6. Lepak, D. P. and Snell, S. A. (2002). Examining the Human Resource Architecture: The Relationships Among Human Capital, Employment, and Human Resource Configurations, Journal of Management, Vol. 28, No. 4, pp. 517-543.
7. Hatch, N. W. and Dyer, J. H. (2004). Human Capital and Learning as a Source of Sustainable Competitive Advantage, Strategic Management Journal, Vol. 25, pp. 1155-1178

8. Youndt, M. and Snell, S. A. (2004). Human Resource Configurations, Intellectual Capital and Organizational Performance, Journal of Managerial Issues, Vol. 16, No. 3, pp. 337-360.

9. Skaggs, B. C. and Youndt, M. (2004). Strategic positioning, Human capital and performance in service: A Customer interaction approach, Strategic Management Journal, Vol. 25, No. 1, pp. 85-99.

10. Yang, C. and Lin, C. Y. (2009). Does intellectual capital mediate the relationship between HRM and organizational performance? Perspective of a healthcare industry in Taiwan, The International Journal of Human Resource Management, Vol. 20, No. 9, pp. 1965-1984.

11. Barrachina, M., López-Cabrales, A. and Valle-Cabrera, R. (2017). How do employment relationships enhance firm innovation? The role of human and social capital, The International Journal of Human Resource Management, Vol. 28, No. 9, pp. 1363-1391.

12. Pasamar, S., Diaz-Fernandez, M. and Rosa-Navarro, M. D. (2019) Human capital: the link between leadership and organizational learning, European Journal of Management and Business Economics, Vol. 28, No. 1, pp. 25-51.

13. Jayashree, M. and Faisal, A. M. (2017). Development of a conceptual model for implementation of total quality management (TQM) and human resource management (HRM): A literature review, International Journal of Applied Business and Economic Research, Vol 15, No. 21, pp.205-214.

14. Faisal, A. M. and Khannan, K. (2017). Implementation of total quality management (TQM) in labour-intensive small and medium-sized enterprises (SMEs): A case study of footwear manufacturing company, International Journal of Applied Business and Economic Research, Vol 15, No. 21, pp. 171-182.

15. Faisal, A. M. (2016). Simulation Modeling and Analysis of Labour-intensive Small and Medium-sized Enterprises for choosing the best alternative production system, Proceedings of IEEE International Conference on Electrical, Electronics and Optimization Techniques, ICEEOT, pp. 3564-3566.

16. https://bpmsg.com/ahp/ahp.php

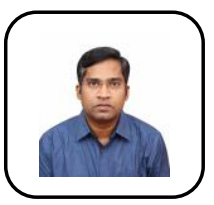

\section{AUTHORS PROFILE}

P. V. S. Kiran, is a Research Scholar in School of Management Studies, Vels Institute of Science, Technology \& Advanced Studies, Chennai, India. He is a seasoned HR professional with rich experiences in people management, having served progressive organizations pivoting on HR. He has demonstrated his expertise in-Talent acquisition, engagement, training, development and personnel management. Successful implementation of compensation policies, rewards and recognition programs He has profound knowledge of HR procedures \& policies and has spearheaded Implementation of performance management and e-HRM(ERP) systems.

His expertise in managing M\&As from HR-perspective and scaling-up HR across sub-verticals \& geographies is legendary, he possesses the knowhow of HR practices of various sectors He has a Bachelors in Law \& Mathematics, MBA, Masters in Psychology, ISTD diploma in Training \& Development. He currently heads the HR function at Hinduja Housing Finance Ltd.

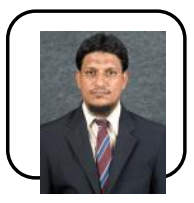

A. Mohammed Faisal is an Assistant Professor in School of Management Studies, Vels Institute of Science, Technology \& Advanced Studies, Chennai, India. He works in Department of Logistics and Supply Chain. He received his $\mathrm{PhD}$ from the Department of Management Studies, Indian Institute Technology (IIT) Madras, Chennai. He has done research in the areas of total quality management and lean manufacturing on labour-intensive small and medium-sized enterprises (SMEs). 